\title{
POTASSIUM DISTRIBUTION IN SURFACE SOILS OF KUST TEACHING, RESEARCH AND COMMERCIAL FARM, GAYA, KANO STATE
}

\author{
Almu H., Abdulkadir N.A., Sani A., Adamu U.K. and Aminu M.A. \\ Department of Soil Science, Kano University of Science and Technology, Wudil, P.M.B \\ 3244, Kano State
}

Cite this article:

Almu H., Abdulkadir N.A., Sani A., Adamu U.K., Aminu M.A. (2021), Potassium Distribution in Surface Soils of Kust Teaching, Research and Commercial Farm, Gaya, Kano State. African Journal of Agriculture and Food Science 4(2), 26-35. DOI: 10.52589/AJAFSQOQKELBV.

\section{Manuscript History}

Received: 17 April 2021

Accepted: 9 May 2021

Published: 14 May 2021

Copyright $\odot 2020$ The Author(s). This is an Open Access article distributed under the terms of Creative Commons AttributionNonCommercial-NoDerivatives 4.0 International (CC BY-NC-ND 4.0 ), which permits anyone to share, use, reproduce and redistribute in any medium, provided the original author and source are credited.
ABSTRACT: A study was conducted on the distribution of potassium in the surface soil of Kano University of Science and Technology teaching, research and commercial farm, Gaya during 2018/2019 session. The contents of different forms of potassium were observed. Water soluble, exchangeable, nonexchangeable, mineral and total potassium were determined in surface soil $(0-15 \mathrm{~cm})$ in KUST teaching, research and commercial farm, Gaya. The results showed that the average values for water soluble $K$, exchangeable $K$, non-exchangeable $K$, mineral $K$ and total $K$ were: $0.14,0.18,0.35,1.36$ and 3.92 $\mathrm{Cmol} / \mathrm{Kg}$ soil respectively. The values for $K$ saturation percentage (KSP) ranged between 0.12-019 and exchangeable $K$ between 0.13-0.20 Cmol/Kg clay. There was a wide variation in the values of various forms of $K$ and among indices associated with mineral composition in different soils. The results show that the values of $K$ form in most of the studied soils are quite low. Consequently, the supplying power of potassium in these soils is low and the need for potassium fertilizer is recommended.

KEYWORDS: Physico-Chemical Properties, Water-Soluble K, Exchangeable K, Non-Exchangeable K, Mineral, Total K. 


\section{INTRODUCTION}

Potassium is the major nutrient element and the most abundant elemental constituent of the soil (Lalitha and Dhakshinamoorthy, 2014). Potassium is a metallic element found naturally in various salts and clay minerals in soils (Strivastava, 2007). Available potassium is a limiting factor in many agricultural and environmental soils. There are equilibrium and kinetic factors between these forms that affect the level of soluble potassium at any particular time, and thus the amounts that are readily available to plants (Jalali and Khanlari, 2014). The amount of soilsoluble potassium is usually too low to meet the requirement of potassium by crops, while the exchangeable potassium is often large enough to satisfy the requirement of one crop but too small to meet the needs of several crops (Sparks and Hung, 2002). Non-exchangeable potassium occupies internal positions of clay sites as well as hexagonal cavities of certain minerals such as illite. Non-exchangeable potassium is moderately to sparingly available to plants (Mengel \& Kirkby, 1987; Al-zubaidai \& El-semok, 2002). The type of potassium bearing minerals greatly affects the release rate of non-exchangeable potassium (Martin \& Sparks, 1983). Soil type pedoclimatic conditions affect the potassium supplying power of Sudan Savanna soils (Darwish et al., 2003). Mineral or structure potassium also known as native matrix - in this form $90-95 \%$ of total potassium is bounded within the crystal structure of various potassium bearing minerals like feldspar and micas. Total potassium represents the sum of all soil potassium forms. There are several factors that affect the quantity of total potassium in soil such as parent material, climate, leaching and vegetative cover. Improving the understanding of the knowledge of potassium dynamics and distribution patterns becomes critical for better agronomic management (Sato et al., 2009). The aim of this research work was to estimate potassium distribution in surface soils in KUST, Wudil research, teaching and commercial farm at Gaya.

\section{MATERIALS AND METHODS}

\section{Sampling Site}

The samples were collected from Kano University of Science and Technology new teaching, research and commercial farm, Gaya. The vegetation of the area is typically the Sudan Savannah region of Northern Nigeria, Gaya (Olopin, 1997) characterized by annual rainfall of $850-857 \mathrm{~mm}$, the bulk of which falls from June to September. The mean annual temperature is about $36^{\circ} \mathrm{C}-38^{\circ} \mathrm{C}$ in the coolest months (December/January) and $35^{\circ} \mathrm{C}$ in the hottest months, with relative humidity of $40 \%$, latitude of $11^{0} \mathrm{~N}-12 ! \mathrm{N}$ and longitude of $7^{0} 30^{!} \mathrm{E}-8^{0} 35 ! \mathrm{E}$. These coordinates are for Gaya zone which falls in Sudan Savanna region of Nigeria (Kano state station of IAR, 2008). The parent materials in the area include aluminium and aeolian sands overlying either aluminium or basement complexes (Lekwa, 1982).

\section{Sampling}

The field was already subdivided into four units or strata before the study in order to have a broader knowledge about the site from which the soil may be collected. These include Animal Production Unit, Grazing Unit, Crop Unit and Forestry Unit. Five samples were collected from each strata/unit randomly within a depth of $0-15 \mathrm{~cm}$ from 5 different locations within $5 \mathrm{~m}^{2}$ from each unit. These samples were air-dried, kept in labelled polythene bags and then taken to the laboratory for analysis. 


\section{Laboratory Analyses}

Composite soil samples were collected, air-dried in a shade, gently ground using wooden pestle and mortar, and passed through $2 \mathrm{~mm}$ and $0.5 \mathrm{~mm}$ sieves to remove coarse fragments. The sieved samples were preserved in polythene bags for further analysis. All the soil samples varied widely in their physico-chemical properties. Particle size distribution of the soil samples was determined using the hydrometer as described by Bouyocos (1951). Soil reaction was determined in a 1:2.5 soil water suspension after stirring for 30 minutes using a $\mathrm{pH}$ meter (Jackson, 1973). Organic carbon content was determined using the Walkley-Black wet oxidation method as described by Nelson and Sommers (1982). The total nitrogen content of the soil was determined using the micro-Kjeldahl technique as described by Bremner and Mulvaney (1982). Available phosphorus was determined by using the Olsen's reagent as extractant by using Spectrophotometer (Jackson, 1973). Available potassium was determined by extracting the soil with neutral normal ammonium acetate, and the contents of $\mathrm{K}$ in solution and a flame photometry was used (Jackson, 1973). Exchangeable bases (Ca, $\mathrm{Mg}, \mathrm{K}$ and $\mathrm{Na}$ ) were extracted with $1 \mathrm{M}$ ammonium acetate $\left(1 \mathrm{M} \mathrm{NH} \mathrm{NHAc}_{4} \mathrm{OA}\right.$ ) solution buffered at $\mathrm{pH} 7.0$ according to Anderson and Ingram (1998). Calcium and Mg in the leachate were determined with atomic absorption spectrophotometer while $\mathrm{K}$ and $\mathrm{Na}$ were determined with flame photometer. Total Exchangeable Bases (TEB) were calculated as the sum of $\mathrm{Ca}, \mathrm{Mg}, \mathrm{K}$ and $\mathrm{Na}$. The effective cation exchange capacity was calculated as the sum of the bases extracted by $1 \mathrm{M} \mathrm{NH} 4 \mathrm{OAc}$ at $\mathrm{pH} 7$ and exchangeable aluminium. The physico-chemical properties of the soil were presented in Table 1 .

Different forms of potassium were estimated by:

\section{Water-soluble potassium}

Water-soluble $\mathrm{K}$ was determined by shaking the soil sample with deionized water. In this method, $5 \mathrm{~g}$ of air-dried soil was placed in a conical flask and $25 \mathrm{ml}$ of distilled water was added (1:5 ratio). This mixture was shaken in a mechanical shaker for an hour and filtered. Potassium was estimated from the filtrate on the flame photometer (Pratt, 1982).

\section{Exchangeable potassium}

Exchangeable $\mathrm{K}$ was obtained by flame photometer using $1 \mathrm{~N}$ neutral ammonium acetate extraction $\left(\mathrm{NH}_{4} \mathrm{OAc}\right)$. This method involved placing $5 \mathrm{~g}$ soil in a conical flask; $2 \mathrm{ml} 1 \mathrm{~N}$ $\mathrm{NH}_{4} \mathrm{OAc}$ was added and shaken for $10 \mathrm{~min}$. The supernatant liquid was decanted into a $100 \mathrm{ml}$ volumetric flask. There were three additional extractions made in the same manner. The combined extractions were diluted to $100 \mathrm{ml}$ with $1 \mathrm{~N} \mathrm{NH}_{4} \mathrm{OAc}$ and $\mathrm{K}$ was determined by flame photometer (Piper, 1966).

\section{Non-exchangeable potassium}

It was determined by using $1 \mathrm{~N}$ boiling $\mathrm{HNO}_{3}$ extraction method. In this method, $2.5 \mathrm{~g}$ of finely ground soil $(1 \mathrm{~mm})$ was placed in a $100 \mathrm{ml}$ Erlenmeyer flask. $2.5 \mathrm{ml}$ of $1 \mathrm{~N} \mathrm{HNO}_{3}$ was added and the flask was placed on a hot electrical plate. The suspension was boiled gently for $10 \mathrm{~min}$. The flask was then removed and after cooling, the content was filtered and the filtrate was received in a $100 \mathrm{ml}$ volumetric flask. The soil was washed four times with $15 \mathrm{ml}$ portions of $0.1 \mathrm{~N} \mathrm{HNO}_{3}$. The solution was diluted to volume, mixed thoroughly and $\mathrm{K}$ was determined using a flame photometer (Pratt, 1982). 


\section{Total potassium}

Total $\mathrm{K}$ was estimated by digesting the soil samples with $\mathrm{HClO}_{4}-\mathrm{HNO}_{3}$ acid mixture and leached with $\mathrm{HCl}$, as described by Rayment and Lyons (2011). The various forms of $\mathrm{K}$ in the respective extracts were determined using the flame photometer.

\section{Mineral potassium}

Mineral $\mathrm{K}$ was determined by subtracting total $\mathrm{K}$ from $\mathrm{HNO}_{3}$ extractable.

\section{RESULTS AND DISCUSSION}

\section{Physico-Chemical Properties of the Soil}

The particle size analysis (Table 1) shows that the texture of the different soil profiles of the different sequences of these areas is predominantly sandy loam in nature. The clay to silt content in these soil profiles contribute to the sandy nature of the parent material (Lekwa, 1982). The $\mathrm{pH}$ values range from medium to high acidity. The medium $\mathrm{pH}$ level with the sample can be attributed to factors such as low rainfall, burning, slow removal of bush due to low cropping intensity and little application of acidifying fertilizers (Beet, 1990). Therefore, the soil of the study area possesses $\mathrm{pH}$ values tolerable to most cultivated crops. Soil contains carbon in both organic and inorganic forms. In most soils (with exception of calcareous soil), the majority of carbon is held as soil organic carbon. Soil organic carbon in the soil ranges from less than $1 \%$ in sandy soils to almost $100 \%$. Soil organic carbon is important for the functioning of ecosystems and agroecosystems, having a major influence on the physical structure and the soil ability to store water and supply nutrients. The total nitrogen is found to be low; this is attributed to the low natural organic matter and other human factors such as burning and removal of crop residues, since the low level of inorganic nitrogen amounts for only a small portion of total nitrogen in the savanna soils (Jone and Wild, 1995). The available phosphorus in the sample is found to be low. Exchangeable bases are also called base cations ( $\mathrm{Ca}, \mathrm{Mg}, \mathrm{K}$ and $\mathrm{Na}$ ) or exchangeable cations which are closely related to the cation exchange capacity (CEC), that is base saturation, which is the fraction of exchangeable cations. The amount of these positively charged cations a soil can hold is described as the CEC. A high CEC is an indication of the potential to hold plant nutrients. Increasing the organic matter content of any soil will help to increase the CEC. From the table, the soil sample has low exchangeable cations.

\section{Exchangeable Potassium}

The content of the exchangeable potassium is shown in Table 2. The ranged value for exchangeable potassium $(0.15-0.27 \mathrm{Cmol} / \mathrm{kg})$ is less than the required value to support the growth of crops, but is often large enough to satisfy the requirement of one crop (Spark \& Huang, 2002). The exchangeable $\mathrm{K}$ represents the fraction of potassium which is adsorbed on external and accessible internal surfaces. These are in equilibrium and are collectively known as the readily available potassium pool (Shaikh et al., 2007). Exchangeable K content of these soils varied from $0.15-0.27 \mathrm{Cmol} / \mathrm{kg}$. The contribution of exchangeable $\mathrm{K}$ towards total $\mathrm{K}$ was 11 to $14 \%$. Considering $125 \mathrm{~kg} \mathrm{ha}^{-1}$ as general critical limits for crops, all the soils were high in exchangeable $\mathrm{K}$. The sand fraction was significantly but negatively correlated with all forms 
of potassium; this may be due to less content of potassium bearing minerals in sand fractions. The present findings are in a similar line as that of Singh et al. (2001) and Gangopadhyay et al. (2005). The better correlation of these forms of potassium with other forms indicates that the different forms of potassium were in dynamic equilibrium with each other.

\section{Soluble Potassium}

Soluble potassium in the study is shown in Table 2. The soluble potassium $\left(\mathrm{H}_{2} \mathrm{O}-\mathrm{K}\right)$ ranged from $0.12-0.19 \mathrm{Cmol} / \mathrm{kg}$ which corresponds to $4.05-74.6 \mathrm{~kg} / \mathrm{ha}$, which is very low and not sufficient to support plant growth being much lower than requirement of most crops.

This amount seemed to be quite inadequate to meet the major part of the requirement of fastgrowing short duration crops for potassium. The level of potassium is too small compared with other potassium forms. Higher values of water-soluble potassium in surface horizons could be attributed to relatively higher amount of clay fractions, and possibly more removal of watersoluble potassium by crops under intensive cultivation from surface horizons. This may be due to less content of potassium bearing minerals in sand fractions. Similar results were also reported by Ghiril and Abtahi (2011), Srinivassarao et al., and Setia and Sharma. The better correlation of these forms of potassium with other forms indicates that the water-soluble potassium was governed by the other forms of potassium like non-exchangeable and total potassium.

\section{Non-exchangeable Potassium}

The values for the non-exchangeable potassium are shown in Table 2. Non-exchangeable $\mathrm{K}$ is generally considered slowly released and the available potassium to the plant under stress situations. The non-exchangeable $\mathrm{K}$ content varied from $0.29-0.52 \mathrm{Cmol} / \mathrm{kg} \mathrm{ha}^{-1}$ with an overall mean value of $0.35 \mathrm{Cmol} / \mathrm{kg}$.

The data show that the value of non-exchangeable $\mathrm{K}$ ranged from $0.29-0.46 \mathrm{Cmol} / \mathrm{kg}$ with a mean value of $0.35 \mathrm{Cmol} / \mathrm{kg}$. The lower amount in surface layers might be due to the release of fixed potassium to compensate for the removal of water-soluble and exchangeable potassium by planting and leaching losses. The non-exchangeable potassium is held between adjacent tetrahedral layers of dioctahedral and trioctahedral mica, vermiculites and integrated clay minerals such as vermiculite (Sparks, 1987). Similar results were reported by Kundu et al., (2014).

\section{Mineral Potassium}

The values of the mineral potassium are shown in Table 2 . The values of the mineral potassium showed variation; they ranged from $0.80-3.0 \mathrm{Cmol} / \mathrm{kg}$ with a mean value of $1.36 \mathrm{Cmol} / \mathrm{kg}$. The content of mineral potassium form depends on the soil types, type of primary and secondary minerals, quantities of clay minerals, the degree of weathering on the particle-size distribution and environmental conditions (Sharpley, 1987; Dhakad et al., 2017). The lowest value of mineral potassium was observed in the crop science unit and the highest value was observed in the grazing unit. This might be due to the sandy nature of the areas, no feldspars, micas and clay minerals or any other activity that favours particle-size distribution. 


\section{Total Potassium}

The values of the total potassium in the studied soils sample are shown in table 2 . They ranged from $0.75-4.90 \mathrm{Cmol} / \mathrm{kg}$ with a mean value of $3.15 \mathrm{Cmol} / \mathrm{kg}$. The higher total $\mathrm{K}$ content in soils may be due to the presence of sufficient quantity of potash bearing primary minerals like feldspar and mica, and it seemed to be directly related with clay and organic matter content of these soils. The reason for the high content of potassium in the lattice structure potassium may be richness in potassium bearing minerals (Sharma et al., 2009). The type of the total potassium depends mainly on the type of parent material, the type of secondary and primary minerals, and soil fraction (Al-Zubaidai and Elsemok, 2002). The factors affecting the forms of potassium were therefore clay minerals, leaching particle size distribution, low CEC of the soil and possible phosphate compounds in the soil (Igwe et al.,2008). Also (Tening et al., 1995), experiment shows that total potassium ranged from $2.30-4.70 \mathrm{Cmol} / \mathrm{kg}$ which is available, forming $1.47 \%$ of the total potassium size distribution in these soils with respect to depths. This agrees with the research finding of Jagmohan and Grewal (2015) and Divya et al., (2016).

Table 1: Some physico-chemical properties of soils at $0-15 \mathrm{~cm}$ depth in KUST Teaching and Research farm, Gaya

\begin{tabular}{|c|c|c|c|c|c|c|c|c|c|}
\hline \multirow[t]{2}{*}{ Treatment } & \multirow[t]{2}{*}{ Texture } & \multirow{2}{*}{\multicolumn{3}{|c|}{ pH (1:1) Org. Carbon (\%) Total N (\%) }} & \multicolumn{5}{|c|}{ Avail. P (ppm) Exchangeable Bases $(\mathrm{Cmol} / \mathrm{kg})$} \\
\hline & & & & & & $\mathrm{Ca}$ & $\mathrm{Mg}$ & $\mathrm{k}$ & $\mathrm{Na}$ \\
\hline ANS 1 & Sandy loam & 7.3 & 0.1596 & 0.014 & 25 & 0.064 & 0.003 & 0.34 & 0.06 \\
\hline ANS 2 & Sandy & 7.1 & 0.1367 & 0.003 & 18 & 0.063 & 0003 & 0.31 & 0.08 \\
\hline ANS 3 & Sandy loam & 6.9 & 0.1197 & 0.012 & 23 & 0.062 & 0.002 & 0.32 & 0.07 \\
\hline ANS 4 & Sandy loam & 7.0 & 0.0998 & 0.009 & 17 & 0.051 & 0.003 & 0.31 & 0.06 \\
\hline ANS 5 & Clay & 7.1 & 0.1995 & 0.017 & 19 & 0.057 & 0.003 & 0.31 & 0.06 \\
\hline CRS 1 & Sandy loam & 7.2 & 0.1596 & 0.016 & 19 & 0.054 & 0.002 & 0.34 & 0.08 \\
\hline CRS 2 & Silt & 7.0 & 0.1594 & 0.015 & 21 & 0.073 & 0.002 & 0.30 & 0.06 \\
\hline CRS 3 & Sandy loam & 7.1 & 0.1567 & 0.013 & 19 & 0.057 & 0.003 & 0.29 & 0.07 \\
\hline CRS 4 & Sand & 6.9 & 0.1297 & 0.018 & 16 & 0.042 & 0.002 & 0.31 & 0.07 \\
\hline CRS5 & Sandy loam & 7.0 & 0.1543 & 0.013 & 19 & 0.061 & 0.002 & 0.31 & 0.05 \\
\hline GRU 1 & Sandy loam & 7.0 & 0.1397 & 0.017 & 15 & 0.082 & 0.002 & 0.29 & 0.07 \\
\hline GRU 2 & Sandy loam & 7.1 & 0.1299 & 0.016 & 17 & 0.071 & 0.003 & 0.30 & 0.08 \\
\hline GRU b & Clay & 7.2 & 0.1495 & 0.014 & 18 & 0.075 & 0.003 & 0.30 & 0.09 \\
\hline GRU 4 & Sandy loam & 7.0 & 0.1544 & 0.009 & 19 & 0.063 & 0.002 & 290. & 0.08 \\
\hline GRU 5 & Silt & 7.1 & 0.1399 & 0.015 & 17 & 0.069 & 0.002 & 0.30 & 0.06 \\
\hline FOR 1 & Sandy loam & 7.2 & 0.0988 & 0.016 & 19 & 0.073 & 0.001 & 0.36 & 0.09 \\
\hline FOR 2 & Sand & 7.1 & 0.1299 & 0.012 & 12 & 0.081 & 0.002 & 0.32 & 0.08 \\
\hline FOR 3 & Sandy loam & 7.0 & 0.1955 & 0.014 & 14 & 0.062 & 20.00 & 0.31 & 0.06 \\
\hline FOR 4 & Sandy loam & 7.0 & 0.1196 & 0.013 & 13 & 0.071 & 0.003 & 0.31 & 0.08 \\
\hline FOR 5 & Silt & 6.9 & 0.1344 & 0.017 & 10 & 0.063 & 0.001 & 0.32 & 0.07 \\
\hline
\end{tabular}


African Journal of Agriculture and Food Science

ISSN: 2689-5331

Volume 4, Issue 2, 2021 (pp. 26-35)

www.abjournals.org

Table 2: Potassium Distribution in the Surface Area of the Study $(\mathrm{Cmol} / \mathrm{kg})$

S/N TREAT EX-K Cmol/Kg SK Cmol/Kg NON-EX K Cmol/Kg MK Cmol/Kg K Cmol/Kg

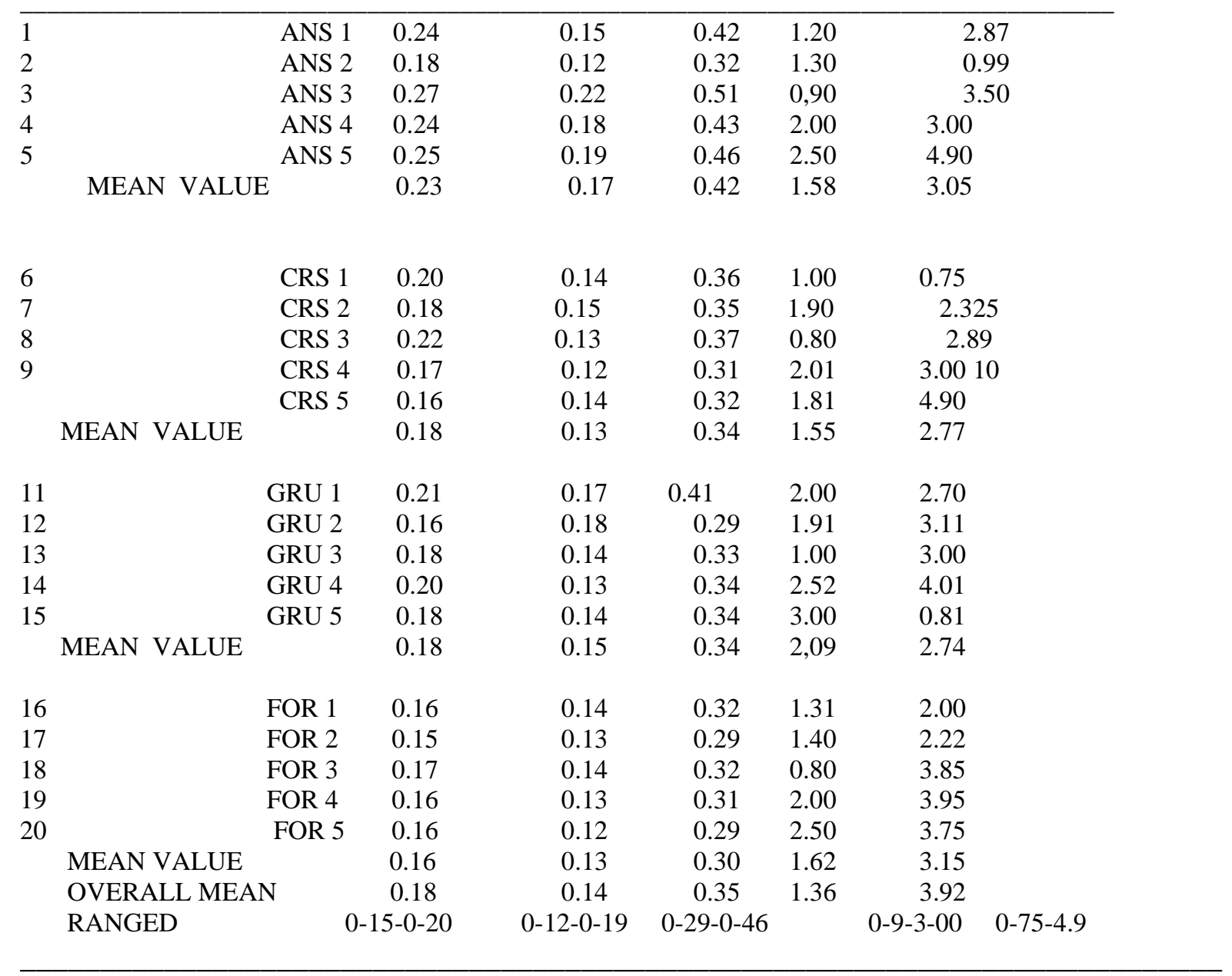

\section{SUMMARY AND CONCLUSION}

The research work was conducted in KUST, teaching, research and commercial farm, Gaya which falls in Sudan Savannah of Nigeria. The project was designed to evaluate the potassium distribution in surface soil $(0-15 \mathrm{~cm})$ in the available farm unit of Wudil research farm. The results of the exercise indicate that all the forms of potassium are low to support plant growth. These result from poor fertility management, continuous cropping or they may be inherited from parent material. The clay and silt in the soil profile contribute to the sandy nature of the soil. The $\mathrm{pH}$ of the soil ranges from low to high acidity which is attributed to factors such as low rainfall, burning, slow removal of bush due to low cropping and application of acidifying fertilizers. This enabled the soil to be productive and retained a sufficient amount of nutrients for crop growth. 


\section{Soil Fertility Rating}

\begin{tabular}{llll}
\hline Characteristics & High & Medium & Low \\
\hline Soil pH (1:1) & $5.0-6.5$ & $4.5-5.5$ & $4.0-4.5$ \\
Organic Carbon (Percentage) & $>20$ & $>-20$ & $<7$ \\
Total nitrogen (percentage) & $>2.0$ & $1.5-2.0$ & $<1.5$ \\
Non-Exchangeable Potassium and & & & \\
Exchangeable Potassium (Cmol $/ \mathrm{kg})$ & $>0.4$ & $0.15-0.4$ & $<0.15$ \\
Mineral Potassium $(\mathrm{Cmol} / \mathrm{kg})$ & $>5$ & 2.5 & $<2$ \\
Total Potassium $(\mathrm{Cmol} / \mathrm{kg})$ & $>6$ & $4-6$ & $<4$ \\
Exchangeable $\mathrm{K}(\mathrm{Cmol} / \mathrm{kg})$ & $>0.4$ & $0.2-0.4$ & $<0.20$ \\
Exchangeable $\mathrm{Ca}(\mathrm{Cmol} / \mathrm{kg})$ & $>10$ & $5.0-10.0$ & $<5.0$ \\
Exchangeable $\mathrm{Na}(\mathrm{Cmol} / \mathrm{kg})$ & $>0.7$ & $0.30-0.70$ & $<1.5$ \\
Exchangeable $\mathrm{Mg}(\mathrm{Cmol} / \mathrm{kg})$ & $>3.0$ & $1.5-3.0$ &
\end{tabular}

Source: Eno et al., 2009

\section{ABBREVIATIONS}

TREAT. - Treatment MK - Mineral Potassium

ANS - Animal Science Unit $\mathrm{K}$ - Total Potassium

CRS - Crop Science Unit

FOR - Forestry Unit

GRU - Grazing Unit

EX K - Exchangeable Potassium

SK - Soluble Potassium

Non Ex K - Non-exchangeable Potassium

\section{REFERENCES}

Ahmad,K (1991) Measurement and assessment ofsoil potassium. IPI Research Topics No. 4 (revised version), International Potash Institute Basel,Switzerland, pp: 102.

Al-zubaidai, A and K. EL-Semok,( 2002): Effect of soil salinity on potassium Equilibrium as related to cropping Mesopotomia journal of Agriculture, 3: 99-105

Anderson, J.M and Ingram, J.S.I (1988): Tropical Soil Biology and Fertility . A Handbook Method. Second Edition C.A.B International Wallingford Oxon OX 10 8DE UK

Beet, W.C (1990):Raising and Sustaining Productivity of Small Holder Farming System in the Tropics, Agric publisher, Alkamaar Netherland pp 175-291

Bouyocos,G.H (1951): A recalibration of the hydrometer for making meachanical analysis of soil. Agro. Jour. 43: 434-438

Bremmer,J.M and Mulvaney,C.S (1982): Determination of Nutrients by kjeldahl Digestion Methods.Methods of Soil analysis, part 2 chemical and microbiological properties, 595625 
Darwish T., T. Masri, M. EI Moujabber and T. Atalla,( 2003): Impactof Soil Nature and Mineral Composition on the Management of available potassium in Lebanese

Soil.Proceeding of the Regional Workshop of the International Potash Intitute. P 152-16

Dhakad, H., Yadav, S. S., Jamra, S., Arya, V., Sharma, K., \& Gaur, D. (2017). Status and Distribution of Different Forms of Potassium in Soils of Gwalior District (MP). IJCS, 5(5), 161-164.

Divya M, Jagadeesh B R, Srinivasa D K, Yogesh G S (2016). Effect of long-term soil fertilizer application on forms and distribution of potassium in soil under rice-cowpea cropping system. An Asian J Soil Sci. 2016; 11(1):10-19.

Eno,J.U, Trenchard O.I, Joseph A. O, Ivara, O and Esu, E (2009): Manual of Soil, Plant and Water Analysis.

Gangopadhyay SK, Sarkar Deepak, Sahoo AK, Das K (2005) Forms and distribution of potassium in some soils of Ranchi plateau. J Indian Soc Soil Sci 53(3): 413-416.

Ghiri M.N., Abtahi A. (2011): Potassium dynamics in calcareous Vertisols of southern Iran. Arid Land Research and Management, 25: 257-274.

Igwe,C.ASS (2008): Factors Affecting Potassium Status of Flood Plains Soils Eastern Nigeria, 54:1-5

Jackson ML (1973) Soil Chemical Analysis. Prentice Hall of India Pvt. Ltd., New Delhi. pp. 98.

Jagmohan S and Grewal K S (2015): Vertical distribution of different forms of potassium and their relationship with different soil properties in some Haryana soil under different crop rotation. Adv. Plant Agril. Res. 2014; 1(2):1-5.

Jalali M and Khanlari Z.V. (2014): Kinetics of potassium release from calcareous soils under different land use. Arid Land Research and Management, 28: 1-13.

Jone, M and Wild,A (1995): Soils of the West African Savanna. Technical Communication on 515 Common Wealth Bureau of Soil.

Kundu MC, Hazra GC, Biswas PK, Mondal S, Ghosh GK. Forms and distribution of potassium in some soils of Hooghly district of West Bengal. J Crop Weed. 2014; 10(2):31-37.

Lalitha and Dhakshinamoorthy (2014). Forms of Patassium: A review National of Soil Survey and Land Use Planning. Bangalore-560 024, Volume 35, Issue 1, India

Lekwa, S (1982): Potassium Exchange Isotherms asa Plant Availability Index in Selected Calcareous Soilsof Western Azarbaijan Province, Iran. Turk J. Afric.For., 30: 21-222.

Martin , H.W and D.L Sparks,( 1983). Kinetics of Non-Exchangeable potassium in soils, Comm. Soil Sci. Anal., 16:133-162.

Mengel K and Kirkby E.A. (1987): Principal of Plant Nutrition. Bern, International Potash Institute.

Nelson and Sommer (1982): Organic Carbon Determination in Acid Sulphate Soils

Olofin, I (1997): Geography Maps World Gazetteer,Google Satellite African Map.Mapldia.com

Piper C S (1966): Soil and Plant Analysis. Hans Publisher, Bombay, 1966, 1-164.

Pratt PF (1982) Potassium methods of soil Analysis. Part II Eds. Page, R.H., Miler and Kenny D.R., American Society of Agronomy, Madison, Wisconsin, USA, 1982, 225 238.

Rayment,G.E and Lyons,D.J (2011): Lab. Methods,Soil Chemical Methods. Research Project Global Innovation Institute of Tech. Innovation Management. Schwarzenbergstr. 95, D21073, Harmburg, Germany. 
Sato S., Morgan K.T., Ozores-Hampton M and Simonne E.H. (2009): Spatial and temporal distributions in sandy soils with seepage irrigation: II. Phosphorus and potassium. Soil Science Society of America Journal, 73: 1053-1060.

Sharma A, Jalali VK, Arya VM, Pradeep R (2009). Distribution of various forms of potassium in soils representing intermediate zone of Jammu region. J Indian Soc. Soil Sci. 2009; 57(2):205-207.

Sheikh, K., Memon, K. S., Memon, M., \& Akhtar, M. S. (2007). Changes in mineral composition and bioavailable potassium under long-term fertilizer use in cotton-wheat system. Soil Environ, 26(1), 1-9

Singh K, Malik RVS, Sing V (2001): Distribution of forms of potassium in alluvial soils. $J$ Potassium Res 17: 116-118.

Sparks, D. L. (1987). Potassium dynamics in soils. In Advances in soil science (pp. 1-63). Springer, New York, NY.

Sparks, H.G, and J.E Hung, ( 2002 ): The contribution of Commercial Fertilizer nutrients to Food production. Agronomy Journal 97: 1 -6.

Strivastava K.S , ( 2007 ): Academic Dictionary, first edition, pp 201

Tening ,H.H. R.S Wild, D.N Olu,( 1995 ): Predicting response to Potassium for soils in Eastern Nigeria

Walkey A and Black AI (1934): Estimation of organic carbon by chromic acid titration method. J Soil Sci. 1934; 25:259-260. 